\title{
The Qualitative Effects of Resveratrol and Coenzyme Q10 Administration on the Gluteus Complex Muscle Morphology of SJL/J Mice with Dysferlinopathy
}

\author{
Efectos Cualitativos de la Administración de Resveratrol y Coenzima Q10 en la Morfología \\ del Complejo Muscular Glúteo de Ratones SJL/J con Disferlinopatía
}

Wendy Jeannette van der Spuy \& Etheresia Pretorius

VAN DER SPUY, W. J. \& PRETORIUS, E. The qualitative effects of resveratrol and coenzyme Q10 administration on the gluteus complex muscle morphology of SJL/J mice with dysferlinopathy. Int. J. Morphol., 29(3):876-884, 2011.

SUMMARY: Dysferlinopathy is a form of muscular dystrophy affecting muscles of the shoulder and pelvic girdles, resulting from inheritance of a mutated dysferlin gene. The encoded dysferlin protein is proposed to be involved in sarcolemmal vesicle fusion with a disrupted plasma membrane; however, with defective protein function these vesicles accumulate beneath the disruption site but are unable to fuse with it and reseal the membrane, thus rendering the membrane repair mechanism defective. The SJL/J mouse model presents with characteristics much like the commonest human condition. Immune modulators have long been under study in the maintenance of muscle health in muscular dystrophies. Such supplementary treatment would ideally suppress inflammation, preventing the immune response toward degenerating muscle from causing additional muscle fiber death, and thus provide a mechanism by which to prolong the life of muscle fibers with inherently defective healing apparatus. For this purpose the anti-inflammatory supplement resveratrol and the membrane-protective supplement coenzyme Q10 were administered separately and in combination to experimental animals to determine their effectiveness in possible therapy of dysferlinopathy. The findings of this study report that low doses of resveratrol and coenzyme Q10 supplementation in exclusivity were unable to afford much protection to muscle fibers at the tissue level. High doses of coenzyme Q10 proved more effective in reducing attenuating inflammation; and combination treatment with resveratrol and coenzyme Q10 provided not only the membrane-protective effects of coenzyme Q10, but also the anti-inflammatory effects of resveratrol which failed to materialize at sufficient levels in exclusive administration.

KEY WORDS: Dysferlinopathy; Coenzyme Q10; Resveratrol; Sarcolemma

\section{INTRODUCTION}

Dysferlinopathy is a form of muscular dystrophy inherited in an autosomal recessive hereditary pattern which affects muscles of the shoulder and pelvic girdles (Angelini, 2002). The myopathy is the result of inheritance of one of a few mutation variants of the dysferlin gene which encodes the dysferlin protein. The dysferlin protein product is proposed to be involved in sarcolemmal vesicle fusion with a disrupted plasma membrane (Bansal et al., 2003; Bansal \& Campbell, 2004), in effect resealing the disruption before an immune response is able to take place. With defective protein function, the sarcolemmal vesicles accumulate beneath a plasma membrane disruption but are unable to fuse with it and reseal the membrane, thus rendering the membrane repair mechanism defective (Bansal et al.; Bansal $\&$ Campbell). Due to this, cells of the immune system are given enough time to initiate a response toward the damage, and the muscle fiber will most likely degenerate and undergo myophagocytosis. It follows that as more damage is incurred to muscle, without prospect of repair, the myopathy takes on an active state and the condition of skeletal muscle will deteriorate, resulting in the myopathy. Dysferlinopathy is additionally characterized by a large degree of inflammation and high levels of muscle fiber regeneration in response to degeneration, as compensation (Bansal et al.). Muscle is thus in a constant state of alteration, with weakening thereof also prominent. 
A successful tool in the study of dysferlinopathy and possible maintenance or therapy thereof is an animal model. The SJL/J mouse model is widely used as it presents with characteristics most like the commonest human condition of dysferlinopathy; characterized by dysferlin deficiency as well as inflammatory changes in muscle (Bittner et al., 1999; Suzuki et al., 2005). The mouse dysferlin gene possesses an overall amino acid sequence homology in excess of ninety percent to the human gene (Vafiadaki et al., 2001), and is also inherited in an autosomal recessive pattern (Bittner et al.; Vafiadaki et $a l$.), making it the optimal means of studying therapeutic options to dysferlinopathy.

Immune modulators have long been under study in the maintenance of muscle health in patients with muscular dystrophies, though not as yet studied in dysferlinopathies specifically (Folkers \& Simonsen, 1995; Jain Foundation Inc., 2008). Treatment with such supplements would ideally suppress inflammation in order to prevent the immune response toward degenerating muscle from causing additional muscle fiber death. The promise of treatment with immune modulators thus lies in the fact that suppression of inflammation could prolong the life of muscles in a disease state known to present with prominent inflammatory characteristics (Jain Foundation Inc.). Modulating the inflammatory response of muscle tissues to the disease condition could thus provide a mechanism by which to prolong the life of muscle fibers with inherently defective healing apparatus.

Resveratrol is an antioxidant and vastly studied antiinflammatory compound found largely in the skins of red grapes (Das et al., 1999; McElderry, 1999; Roy \& Lundy, 2005; Mitchell, 2008; Palsamy \& Subramanian, 2008). This compound is known to enhance nitric oxide production (Mitchell), which through certain mechanisms supports the suppression of damaging effects which leukocytes such as macrophages and neutrophils may have on cells and tissues (Mitchell et al., 1995; Rando, 2001; Tidball, 2005; Hodgetts et al., 2006; Toumi et al., 2006). Neutrophils are the primary cells of an inflammatory response and are proposed to be largely responsible for the inflammation at onset of the dysferlinopathic disease process (Hodgetts et al.).

Coenzyme Q10 is an endogenous antioxidant which protects cells and tissues from the harmful effects of free radicals on proteins (thus DNA) and lipids (thus membranes) as well as other cellular components (NIH, 2008). Under normal circumstances, high concentrations thereof are present in skeletal muscle; but levels decline with age as there are increased requirements for the antioxidant and decreased production of it by the body (NIH). Levels thereof are reported to be low in muscular dystrophies (Folkers \& Simonsen); thus, as with the aged state, the levels of coenzyme Q10 may well rapidly decline with the loss of muscle homeostasis in dysferlinopathy as the body's requirement is increased but the antioxidant's production remains at normal levels. Due to its lipid solubility coenzyme Q10 is recommended as a membrane protective supplement (Folkers \& Simonsen; MedlinePlus, 2007; NIH), which was a factor of great interest to the study.

Previous research conducted by Potgieter and colleagues in 2011 showed that resveratrol and coenzyme Q10 had positive effects on the prominently affected muscle groups (i.e. quadriceps) of dysferlinopathy (Potgieter et al., 2011). The question thus arose whether changes in morphology are visible in less affected muscle groups (i.e. gluteus complex) with administration of these products. In the current research, it is thus hypothesized that resveratrol and coenzyme Q10, separately and in combination will provide membrane-protective and inflammatory-protective effects on gluteus complex muscles in animals of the SJL/J mouse model. This study therefore investigated the effect of resveratrol and coenzyme Q10 on the ultrastructure of muscle fibers by using light and transmission electron microscopy (TEM).

\section{MATERIAL AND METHOD}

Implementation of the mouse model. Female mice consisting of 14 week old Dysferlinopathic SJL/J and 15 week old normal SWR/J mice (each an average weight of $20 \mathrm{~g}$ ) were maintained and housed at the laboratory animal facility of the University of Pretoria Biomedical Research Centre (Pretoria, South Africa) through which ethical clearance was obtained. The animals were maintained in the facility's barrier unit in Tecniplast cages with individual air supply. All experimental procedures were carried out in strict accordance with the requirements of the University of Pretoria's Animal Use and Care Committee.

Animals were divided into seven experimental groups consisting of eight animals in each, displayed in (Table I), which depicts the strain of animal in each of the groups as well as the treatment and dosages administered to them. Six randomly selected SJL/J animals were terminated for time-control results at this time. The remainder of the animals were entered into a 90 day experimental period, treatment administered as follows: control groups received a placebo in the same volume as the animals who received the supplements tested in the study. 
Experimental groups received volumes of resveratrol and coenzyme Q10 (CoQ10) in dosages displayed in (Table I). All dosing was performed orally once daily. The study was effectively concluded when the animals had reached approximately 27 and 28 weeks of age respectively for SJL/ $\mathrm{J}$ and SWR/J mice. Termination procedures were thus performed for the time-control (B) group at 14 weeks of age, for remaining SJL/J (C-G) groups (positive controls and four experimental groups) at 27 weeks of age and for negative control (A) SWR/J mice at 28 weeks of age.

Tissue preparation for microscopy. Muscle biopsies of the gluteus complex were taken from the left hand side of each animal for microscopic analysis and investigation of changes in muscle morphology. The gluteus complex is not commonly studied in research related to dysferlinopathy; this complex is however one of the muscles directly associated with the pelvic girdle, and is of interest as a muscle believed to be largely involved in the weakness experienced in Dysferlinopathic animals.

Light microscopy samples were prepared as follows: biopsies were placed into a $2.5 \%$ formaldehyde fixative for at least one hour. Tissue samples were rinsed three times for 15 minutes each with $0.075 \mathrm{M}$ sodium phosphate buffer, after which series dehydration was performed in 30\%, 50\%, 70\%, $90 \%$ and three times absolute ethanol for periods of 10 minutes each. Once dehydrated, tissue samples were infiltrated with LR-White resin for one hour, changed and subsequently infiltrated for two days. Finally, tissue samples were individually embedded in LR-White resin in gelatin capsule moulds, placed in an oven at $60^{\circ} \mathrm{C}$ for approximately 39 hours in order to properly polymerize the samples for microtoming. Samples were cut at an approximate thickness of $1 \mu \mathrm{m}$ and placed onto glass slides. All light microscopic slides were stained using Toluidine Blue at a $\mathrm{pH}$ of approximately 11.5 , dried and mounted with cover-slips. Light microscopic analysis followed using a Nikon Optiphod Transmitted Light Microscope.
Electron microscopic preparation of samples continued as follows: biopsies were placed into fixative of $2.5 \%$ formaldehyde and $2.5 \%$ glutaraldehyde for at least one hour. Tissue samples were rinsed three times for 15 minutes each with $0.075 \mathrm{M}$ sodium phosphate buffer, after which the samples were placed in a $1 \%$ osmium tetraoxide $(\mathrm{OsO} 4)$ secondary fixative for one hour. After a second round of rinsing three times for 15 minutes each in $0.075 \mathrm{M}$ sodium phosphate buffer, series dehydration was performed in $30 \%$, $50 \%, 70 \%, 90 \%$ and three times absolute ethanol for a period of 10 minutes each. Once dehydrated, TEM tissue samples were infiltrated with a Quetol Epoxy resin in a 1:1 ratio with $100 \%$ ethanol for one hour, then changed and infiltrated in resin exclusively overnight. Samples were finally embedded with Quetol Epoxy resin in rubber moulds and allowed to polymerize in an oven at $60^{\circ} \mathrm{C}$ for approximately 39 hours for ultramicrotoming. Samples were subsequently cut at a thickness of approximately 70-100nm and placed onto copper grids. These were contrast stained using uranyl acetate and Reynolds lead citrate, rinsing the samples 16 times in triplicate with distilled water and dabbing on filter paper to dry after each staining step. Transmission electron microscopic analysis followed using a JEOL Transmission Electron Microscope (JEM 2100F).

\section{RESULTS}

Characteristics most representative of dysferlinopathy were scrutinized throughout the sample and are labeled as such in the Figures. Photomicrographs were taken using light microscopy as well as transmission electron microscopy and each of these subsets analyzed for various characteristics or the lack thereof. Light microscopic micrographs (Fig.1) underwent qualitative morphological analysis, scoring thereof recorded with regards to fiber and infiltrative characteristics as well as the presence of myogenic stem cells (satellite cells).

Table I. Subdivision of experimental animals into groups, indicating the supplementary treatment dosages administered to each animal within respective groups, as well as the age of the mice at which termination was performed

\begin{tabular}{|c|c|c|c|c|}
\hline Experimental Group & Strain & Treatment & $\begin{array}{c}\text { Treatment Dosage } \\
(\mathrm{mg} / \mathrm{kg} / \text { day })\end{array}$ & $\begin{array}{c}\text { Age at Termination } \\
\text { (weeks) }\end{array}$ \\
\hline A. Negative Control & SWR/J & None & - & 28 \\
\hline B. Time-control & $\mathrm{SJL} / \mathrm{J}$ & None & - & 14 \\
\hline C. Positive Control & SJL/J & None & - & 27 \\
\hline D. Resveratrol & SJL/J & Resveratrol & 60 & 27 \\
\hline E. Low-CoQ $Q_{10}$ & $\mathrm{SJL} / \mathrm{J}$ & Coenzyme $\mathrm{Q}_{10}$ & 40 & 27 \\
\hline F. High-CoQ ${ }_{10}$ & $\mathrm{SJL} / \mathrm{J}$ & Coenzyme $\mathrm{Q}_{10}$ & 120 & 27 \\
\hline G. Combination & $\mathrm{SJL} / \mathrm{J}$ & Resveratrol/Coenzyme $\mathrm{Q}_{10}$ & $60 / 40$ & 27 \\
\hline
\end{tabular}



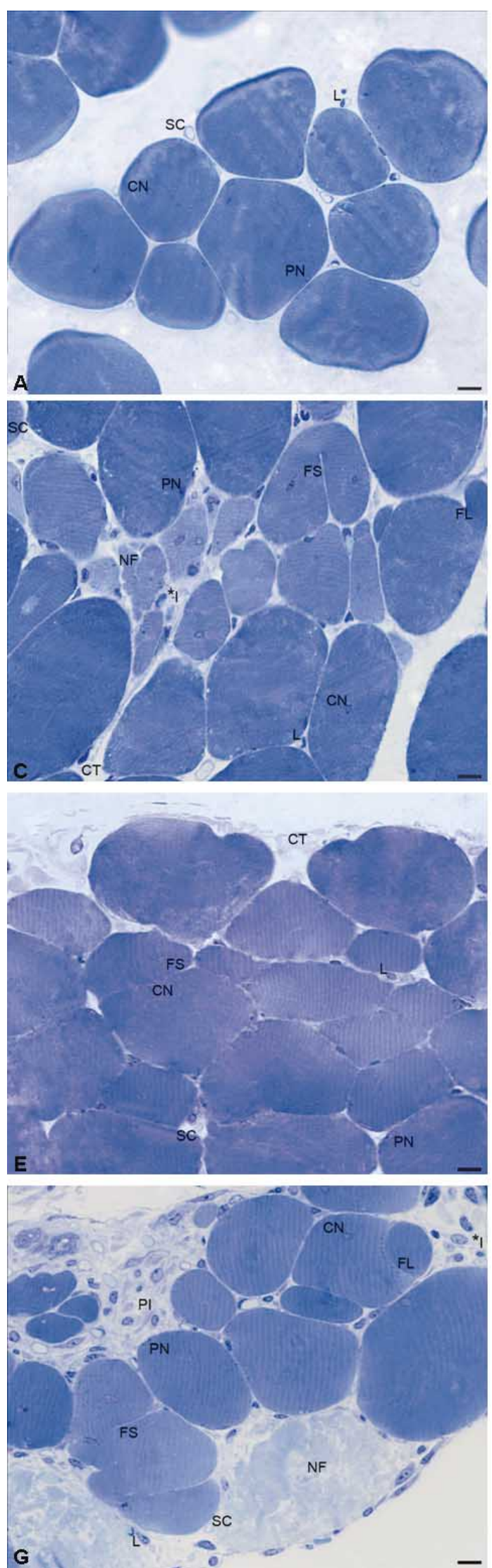
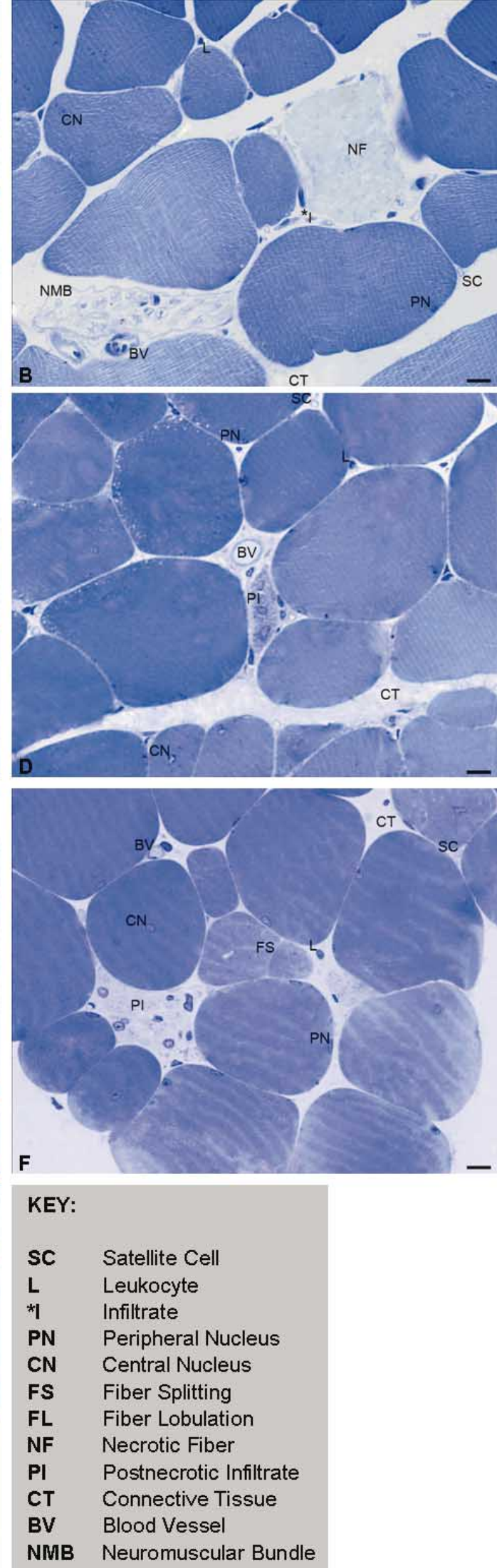

Fig. 1: Depicting morphological differences between gluteus complex muscles in groups AG. All muscle sections were photographed under $40 \mathrm{X}$ magnification. Labels A-G are group specific, thus, A: Negative Control SWR/J mice at 28 weeks of age. B: Baseline untreated $\mathrm{SJL} / \mathrm{J}$ mice at 14 weeks of age. C: Positive Control; D: Resveratrol treated; E: Low-CoQ10 treated; F: HighCoQ10 treated; and G: Combination Resveratrol/CoQ10 treated SJL/J mice at 27 weeks of age. $($ Scale bar $=10 \mu \mathrm{m})$ 
Table II. Adjusted scoring of light microscopic changes observed in micrographs of gluteus maximus muscle samples, with standard deviation between groups indicated for each characteristic scored.

\begin{tabular}{|c|c|c|c|}
\hline \multirow[b]{2}{*}{ Experimental Group } & \multicolumn{3}{|c|}{ Scoring of Gluteus Maximus Light Microscopic Changes } \\
\hline & Fiber Characteristics & Infiltration and/or Proliferation & Satellite Cells \\
\hline A. Negative Control & 20 & 10 & 80 \\
\hline B. Time-control & 60 & 20 & 60 \\
\hline C. Positive Control & 76 & 60 & 80 \\
\hline D. Resveratrol & 80 & 45 & 60 \\
\hline E. Low-CoQ $Q_{10}$ & 48 & 25 & 60 \\
\hline F. High-CoQ ${ }_{10}$ & 48 & 45 & 80 \\
\hline G. Combination & 76 & 60 & 80 \\
\hline \multicolumn{4}{|c|}{ Standard Deviation Between } \\
\hline Groups & 21.52297 & 19.76047 & 10.69045 \\
\hline
\end{tabular}
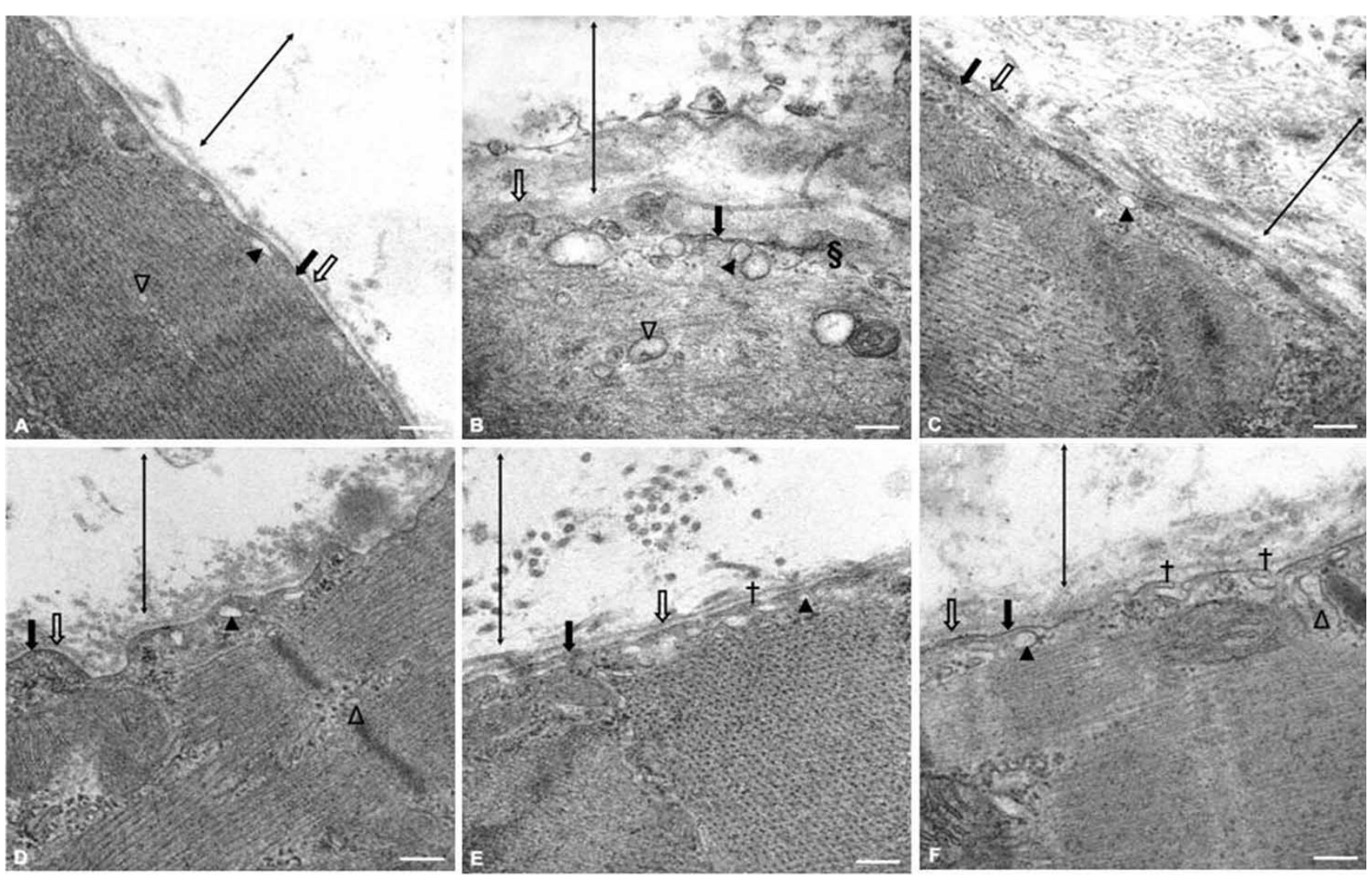
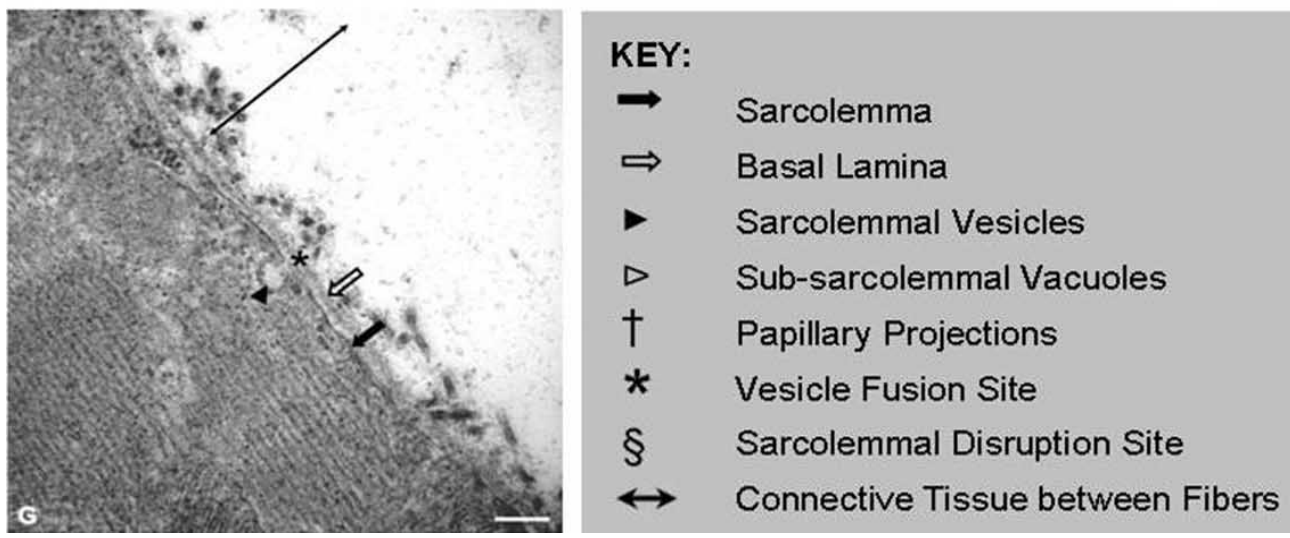

Fig. 2. Morphological differences between gluteus complex muscle membranes in animals under investigation. All muscle sections were photographed at a magnification of approximately 60,000X.
A: Negative Control SWR/ $\mathrm{J}$ mice at 28 weeks of age. B: Baseline untreated SJL/ $\mathrm{J}$ mice at 14 weeks of age. C: Positive Control;

D: Resveratrol treated (60 $\mathrm{mg} / \mathrm{kg} /$ day);

E: Low-CoQ 10 treated (40 $\mathrm{mg} / \mathrm{kg} /$ day);

F: High-CoQ10 treated (120 mg/kg/day);

$\mathrm{G}$ : C o m b i n a t i o $\mathrm{n}$ Resveratrol $/ \mathrm{CoQ}_{10}$ treated (60/40 mg/kg/day) SJL/J mice at 27 weeks of age. $($ Scale bar $=200 \mathrm{~nm})$ 
Transmission electron ultramicrographs (Fig. 2) underwent morphological analysis concentrated upon the sarcolemma and vesicle accumulation and fusion therewith.

Scoring of light microscopic changes (Selcen et al., 2001, Fanin \& Angelini, 2002, Bansal et al., Ho et al., 2004, Cennachi et al., 2005) in the gluteus complex muscles in each of the seven groups (A-G) was performed, with a score of zero allocated for no changes and a maximum score of four allocated to prominent change, i.e. the maximal presence of each variable examined. Scoring for each category was then totaled and these values adjusted to generate Table II (with a maximum value of 80 per category scored). Examination was performed on a qualitative basis through the scrutiny of at least 20 micrographs per animal in each group for the presence of each of the following observations under three categories: Fiber Characteristics - size variability, splitting and lobulation, degeneration and/ or necrosis, and regeneration (central nuclei); Infiltration/ Proliferation - leukocyte (inflammatory, post-necrotic, and regenerative), perivascular, fibrotic or connective tissue, and adipocytic; and finally the presence of Satellite Cells.

Regardless of the presence of multiple characteristics, only one of each is marked in each of the micrographs in Figure 1. The micrographs serve to present the morphological differences between gluteus complex muscles in groups A-G, with reference to the characteristics mentioned above. A summary of adjusted scores for light microscopic changes assessed within the entire sample is shown in Table II; these include the various fiber characteristics, infiltrative and proliferative changes as well as the presence of satellite cells as set out above.

From the light microscopic scoring in Table II, it is evident that fiber characteristics are significantly different when comparing the negative control SWR/J mice (A) to all $\mathrm{SJL} / \mathrm{J}$ mice (B-G). Inflammatory infiltrate and/or connective tissue proliferation are significantly higher than the negative controls (A) only in the positive controls (C), resveratrol (D), high-CoQ10 (F) and combination $(\mathrm{G})$ treated animals. The presence of satellite cells indicates that the animals with the highest muscle regenerative capacity are the ones in the negative (A) and positive (C) controls' as well as those in the high-CoQ10 (F) and combination $(\mathrm{G})$ treated groups.

Examination of transmission electron microscopic morphological variables (Selcen et al.; Ho et al.) was concentrated on the sarcolemma as well as vesicle accumulation beneath the sarcolemma and/or fusion therewith. Ultramicrographs in Figure 2 serve to provide the morphological observations most representative of the gluteus complex muscles in animals within each of the seven groups (A-G). Defects (basal lamina thickening, presence of papillary projections) and discontinuity of the sarcolemma as well as the lack of fusion of sarcolemmal vesicles with the sarcolemma are representative of the muscle's inability to repair itself and thus indicative of prospective degeneration of the muscle tissue.

\section{DISCUSSION}

Taken together, light microscopic and transmission electron microscopic analysis reveal the following: The negative control (A) group displayed typical healthy muscle. Degenerative changes were at an absolute minimum, regenerative changes were also at a minimum, and regenerative capabilities i.e. satellite cell numbers were at maximal levels. Sarcolemmal integrity as well as the basal lamina were normal though some sarcolemmal vesicles and sub-sarcolemmal vacuoles were present, suggesting the ability to promptly repair a site of injury should it occur in this massively utilized muscle complex. The presence of collagen bundles was insignificant at an ultrastructural level. The gluteus complex muscle is prominent and much exercise and stretching will necessitate the need for an efficient repair mechanism, thus it is conceivable that the evident presence of large numbers of sarcolemmal vesicles in the vicinity allow for prompt repair of a site of injury should it occur in this massively utilized muscle complex. This group is the model to which treated groups were compared in order to determine the status of muscular wellbeing.

The time-control (B) group possessed minimal regenerative and degenerative changes, as well as moderate regenerative capabilities, closer to that observed in the negative control (A) group than the positive control (C) group. Ultrastructurally however, a different representation was apparent, large vesicles and areas of membrane disruption were observed along with an indistinct and/or very thick basal lamina in places. It would seem that in a largely utilized muscle complex, the 14 week old SJL/J mouse possesses a great ability to. This group provided the comparison standard for groups administered supplementary treatment, allowing the determination of enhancement in muscle wellbeing from 14 to 27 weeks of age.

The positive control (C) group possessed moderate to maximal degenerative changes, and presented with maximal regenerative changes and capabilities. Sarcolemmal defects were however pronounced, as were basal lamina thickening and vesicle accumulation. 
Inflammatory infiltrate within muscle samples of this group was marked, and collagen bundles were observed in excess, indeed in the highest levels when compared to all other groups under investigation. This group was thus the standard of moderate to advanced dysferlinopathy to which treated groups were compared. It would thus seem that in this muscle group, more damage is incurred in the earliest stages of disease, and the muscles themselves may be able to compensate for this as the myopathy progresses.

When comparing the four experimental groups, the following was observed; resveratrol (D) administration showed a maximal balance between regenerative and degenerative changes, with only moderate regenerative capabilities being evident. Vesicles and membrane defects were visible ultrastructurally, the basal lamina possessed areas of thickening and structural alteration. Much inflammatory infiltrate was apparent, and collagen fibers were marked but not in excess. It appears that the exclusive anti-inflammatory role of resveratrol is ineffective in a prominently utilized muscle complex.

The low-CoQ10 (E) treated group showed minimal to moderate degenerative as well as regenerative changes, and moderate regenerative capabilities. Many sarcolemmal vesicles, with areas of fusion with and thus repair of the sarcolemma was evident. Some discontinuity of the membrane was however also evident. Additionally, basal lamina thickening and papillary projections were observed. Inflammatory infiltration was marked; but collagen fibers were not present in large amounts. Low-CoQ10 administration does seem to be marginally membrane protective in the case of gluteus complex muscles, but is not successful in protecting the fibers to a large extent as some discontinuity is visualized, with the overall state of muscle similar to that of the time-control (B) group.

High-CoQ10 (F) administration was shown to present muscle fibers with minimal degenerative changes and moderate to maximal regenerative changes and capabilities. Though large vesicles, thickening of the basal lamina and some papillary projections were evident, collagen fiber presence was not at all striking. This treatment option seemed to be more effective in improving the condition of muscle fibers from 14 to 27 weeks of age than the above two treatment options (groups D and E). Muscle fibers were in every respect closer to the state of health observed in the negative control (A) group than to either 14 or 27 week old untreated SJL/J mice of the time-control (B) or positive control (C) groups.

The combination $(\mathrm{G})$ treated group displayed moderate to maximal regenerative changes and capabilities as well as maximal degenerative changes. Ultrastructurally, few vesicles were evident with some fusion thereof with the sarcolemma observed and only a small degree of basal lamina thickening present. The state of inflammatory infiltration was not striking within the animals of this group. On ultrastructural level, the combination treatment appeared to display an integrated beneficence of both supplementation treatment options, in that the anti-inflammatory effects of resveratrol was visible and the membrane protective effects of CoQ10 were marked even though the combination treated group was administered a low concentration of this supplement. Adding weight to this treatment option were additional findings that the combination treated group possessed the lowest neutrophil, eosinophil and monocyte counts overall.

Cumulatively, it is apparent that resveratrol and lowcoenzyme Q10 administration in exclusivity were unable to afford much protection to muscle fibers at the tissue level, both in terms of inflammation suppression and membrane protective capabilities. High-coenzyme Q10 administration offered convincing protection against membrane damage and improved muscle fiber wellbeing dramatically from a timecontrol age of 14 weeks to the age of positive control animals at 27 weeks. The combination resveratrol/coenzyme Q10 administration provided not only membrane protective effects more likened to that observed in the high-coenzyme Q10 than the low-coenzyme Q10 treated group, but also provided the anti-inflammatory effects of resveratrol which failed to materialize at sufficient levels in exclusive resveratrol administration.

In 2011, Potgieter and coworkers showed that high doses of coenzyme Q10 as well as combination resveratrol/ coenzyme Q10 markedly reduced the inflammatory insult characteristic of dysferlinopathy in the prominently affected quadriceps muscle (Potgieter et al. 2011). The results of the present study show the same to be evident in less affected muscle groups. Thus in conclusion, the efficiency of supplementary treatment with either high-coenzyme Q10 or combination resveratrol/coenzyme Q10 was supported in the findings of a less affected muscle group such as those of the gluteus complex, in that the supplements effectively decreased the ongoing inflammatory process characteristic of dysferlinopathy.

\section{ACKNOWLEDGEMENTS}

The authors wish to that Dr. Marnie Potgieter, for the animal study supervision. The authors also wish to thank the National Research Foundation of South Africa (NRF) for 
funding E.P. [Indigenous Knowledge Systems (FA2004033100004)]. The authors have no conflict of interest and additionally have no financial interests in the products reviewed in this paper.

VAN DER SPUY, W. J. \& PRETORIUS, E. Efectos cualitativos de la administración de resveratrol y coenzima Q10 en la morfología del complejo muscular glúteo de ratones SJL/J con disferlinopatía. Int. J. Morphol., 29(3):876-884, 2011.

RESUMEN: Disferlinopatía es una forma de distrofia muscular que afecta a los músculos de los hombros y cintura pélvica, resultado de la herencia y mutación del gen de la distrofina. Sugerimos que la proteína codificada distrofina que integra la estructura sarcolemal con una membrana plasmática interrumpida, que al presentar una proteína defectuosa, las estructuras se acumulan debajo del sitio de alteración sin lograr fundirse con éste y cerrar la membrana afectando el mecanismo de reparación. El modelo de ratón SJL / J se presenta con características muy similares a una condición humana común. Los inmunomoduladores han sido objeto de estudio en el mantenimiento de la salud muscular en las distrofias musculares. Este tipo de tratamiento suplementario puede ser ideal para suprimir la inflamación, en la prevención de la respuesta inmune en la degeneración muscular causando la muerte adicional de fibra muscular, y al mismo tiempo proporcionar, un mecanismo con el cual prolongar la vida útil de aquellas fibras musculares con el aparato de sanación comprometido. Para ello, el Resveratrol suplemento anti-inflamatorio y el suplemento protector de membrana coenzima Q10 se administró por separado y en combinación en los animales de laboratorio para determinar su efectividad en el tratamiento de posible disferlinopatía. Los resultados de este estudio indican que el Resveratrol en menor dosis y la coenzima Q 10 administrados como suplementos de manera exclusiva, no demostraron efectos de protección de las fibras musculares a nivel del tejido. Una alta dosis de coenzima Q10 demostró ser más efectiva en la reducción de la inflamación; adicionalmente, el tratamiento combinado de Resveratrol y coenzima Q10 proporcionó efectos protectores de membrana, además de los efectos anti-inflamatorios del Resveratrol cuyo nivel no alcanzó la efectividad suficiente al ser administrado en forma exclusiva.

PALABRAS CLAVE: Disferlinopatía; Coenzima Q10; Resveratrol; Sarcolema.

\section{REFERENCES}

Angelini, C. Advances and perspectives in muscular dystrophies. Basic Appl. Myol., 12(1):17-25, 2002.

Bansal, D. \& Campbell K. P. Dysferlin and the plasma membrane repair in muscular dystrophy. Trends Cell Biol., 14(4):206-13, 2004.

Bansal, D.; Miyake, K.; Vogel, S. S.; Groh, S.; Chen, C. C.; Williamson, R.; McNeil, P. L. \& Campbell, K. P. Defective membrane repair in dysferlin-deficient muscular dystrophy. Nature, 423:168-72, 2003.

Bittner, R. E.; Anderson, L. V. B.; Burkhardt, E.; Bashir, R.; Vafiadaki, E.; Ivanova, S.; Raffelsberger, T.; Maerk, I.; Höger, H.; Jung, M.; Karbasiyan, M.; Storch, M.; Lassmann, H.; Moss, J. A.; Davison, K.; Harrison, R.; Bushby, K. M. \& Reis, A. Dysferlin deletion in SJL mice (SJL-Dysf) defines a natural model for limb girdle muscular dystrophy 2B. Nat. Genet., 23:141-2, 1999.

Cenacchi, G.; Fanin, M.; De Giorgi, L. B. \& Angelini C. Ultrastructural changes in dysferlinopathy support defective membrane repair mechanism. J. Clin. Pathol., 58:190-5, 2005.

Das, D. K.; Sato, M.; Ray, P. S.; Maulik, G.; Engelman, R. M.; Bertelli, A. A. \& Bertelli, A. Cardioprotection of

red wine: role of polyphenolic antioxidants. Drugs Exp. Clin. Res., 25:115-20, 1999.

Fanin, M. \& Angelini, C. Muscle pathology in dysferlin deficiency. Neuropath. Appl. Neurobiol., 28:461-70, 2002.

Folkers, K. \& Simonsen, R. Two successful double-blind trials with coenzyme Q10 (vitamin Q10) on muscular dystrophies and neurogenic atrophies. Biochim. Biophys. Acta, 1217:281-6, 1995.

Ho, M.; Post, C. M.; Donahue, L. R.; Lidov, H. G.; Bronson, R. T.; Goolsby, H.; Watkins, S. C.; Cox, G. A. \& Brown, R. H. Jr. Disruption of muscle membrane and phenotype divergence in two novel mouse models of dysferlin deficiency. Hum. Mol. Genet., 13:19992010, 2004.

Hodgetts, S.; Radley, H.; Davies, M. \& Grounds M.D. Reduced necrosis of dystrophic muscle by depletion of host neutrophils, or blocking TNFa function with Etanercept in mdx mice. Neuromuscul. Disord., 16:591602, 2006.

Jain Foundation Inc. Research into Miyoshi/LGMD2B. 2008. 
McElderry, M. Q. B. Grape Expectations: The Resveratrol Story. Quackwatch Web site, 1999. Available at: http:// www.quack-watch.com.

MedlinePlus. Herbs and Supplements: Coenzyme $Q_{10} 2007$. Avaible at: http://www.nlm.nih.gov/medlineplus/ druginfo/natural/938.html

Mitchell, C. A.; Grounds, M. D. \& Papadimitriou, J. M. The genotype of bone marrow-derived inflammatory cells does not account for differences in skeletal muscle regeneration between SJL/J and BALB/c mice. Cell Tissue Res., 280:407-13, 1995.

Mitchell, T. Resveratrol: cutting-edge technology available today. Life Extension Foundation. 2008.

NIH: National Institutes of Health. Coenzyme Q10. 2008.

Palsamy, P. \& Subramanian, S. Resveratrol, a natural phytoalexin, normalizes hyperglycemia in streptozotocin-nicotinamide induced experimental diabetic rats. Biomed. Pharmacother., 62:598-605, 2008.

Potgieter, M.; Pretorius, E.; Van der Merwe, C.F.; Beukes, M.; Viera, W. A.; Auer, R.E.G.; Auer, M. \& Meyer, S. Histological assessment of SJL/J mice treated with the antioxidants coenzyme $\mathrm{Q}_{10}$ and resveratrol. Micron., 42:275-82, 2011.

Rando, T. A. Role of nitric oxide in the pathogenesis of muscular dystrophies: a "two-hit" hypothesis of the cause of muscle necrosis. Microsc. Res. Tech., 55:223-35, 2001.

Roy, H. \& Lundy, S. Resveratrol. Pennington Nutrition Series, 7, 2005.

Selcen, D.; Stilling, G. \& Engel, A. G. The earliest pathologic alterations in dysferlinopathy. Neurology, 56:1472-81, 2001.

Suzuki, N.; Aoki, M.; Hinuma, Y.; Takahashi, T.; Onodera, Y.; Ishigaki, A.; Kato, M.; Wartia, H.; Tateyama, M. \& Itoyama, Y. Expression profiling with progression of dystrophic change in dysferlin-deficient mice (SJL). Neurosci. Res., 52:47-60, 2005.

Tidball, J. G. Inflammatory processes in muscle injury and repair. Am. J. Physiol. Regul. Integr. Comp. Physiol., 288:R345-53, 2005.

Toumi, H.; F'guyer, S. \& Best, T. M. The role of neutrophils in injury and repair following muscle stretch. J. Anat., 208:459-70, 2006.

\section{4}

Vafiadaki, E.; Reis, A.; Keers, S.; Harrison, R.; Anderson, L. V. B.; Raffelsberger, T.; Ivanova, S.; Hoger, H.; Bittner, R. E.; Bushby, K. \& Bashir, R. Cloning of the mouse dysferlin gene and genomic characterization of the SJL-Dysf mutation. Neuroreport, 12(3):625-9, 2001.
Correspondence to:

Prof. E. Pretorius

Department of Physiology

Private Bag X·23, ARCADIA

0007, SOUTH AFRICA

Tel number: +27 124202864

Fax: $\quad+27124204483$

E-mail: resia.pretorius@up.ac.za

Received: 14-02-2011

Accepted: 14-07-2011 